\title{
URGENSI BERDIRINYA BANK SENTRAL SYARIAH
} DI INDONESIA

\author{
Agus Pandoman*) \\ Fakultas Hukum Universitas Cokroaminoto Yogyakarta \\ apandoman@gmail.com \\ *Penulis koresponden \\ \begin{tabular}{|l|l|l|}
\hline Diajukan: 16-02-2019 & Diterima: 19-02-2019 & Diterbitkan: 24-02-2019
\end{tabular}
}

\begin{abstract}
Bank Indonesia has been established as a central bank that develops dual monetary policies that drag the legal concepts of conventional banks and Islamic banks into ambiguous. This paper identifies the challenges faced in Islamic financial policy that are different from other monetary policies. With the legal historical approach it can be concluded that it is important to establish a Sharia Central Bank in Indonesia, as a monetary controller that is independent and separate from Bank Indonesia. Islamic banks must be in the legal corridor of the Islamic Central Bank. Profits obtained by Sharia Banks are not based on a sevendays rate policy, but must be based on the profit of the bank's cooperative profit financed based on an analysis projection from the Sharia Central Bank. This is where the urgency of the establishment of the Central Bank of Sharia in Indonesia, as a center for sharia-based monetary supervision as well as a form of manifestation of a real economic muamalah with gold-standard exchange instruments.
\end{abstract}

Keywords: Urgency, Bank Indonesia, Islamic central bank

Abstrak: Bank Indonesia telah ditetapkan sebagai bank sentral yang mengembangkan kebijakan moneter ganda yang menyeret konsep hukum bank konvensional dan bank syariah menjadi ambigu. Makalah ini mengidentifikasi tantangan yang dihadapi dalam kebijakan keuangan Islam yang berbeda dari kebijakan moneter lainnya. Dengan pendekatan historis hukum dapat disimpulkan bahwa penting untuk mendirikan Bank Sentral Syariah di Indonesia, sebagai pengendali moneter yang independen dan terpisah dari Bank Indonesia. Bank syariah harus berada di koridor hukum Bank Sentral Islam. Keuntungan yang diperoleh oleh Bank Syariah tidak didasarkan pada kebijakan tingkat bunga mingguan, tetapi harus didasarkan pada laba dari laba koperasi bank yang dibiayai berdasarkan analisis dari Bank Sentral Syariah. Di sinilah urgensi pendirian Bank Sentral Syariah di Indonesia, sebagai pusat pengawasan moneter berbasis syariah serta sebagai wujud manifestasi muamalah ekonomi riil dengan instrumen pertukaran standar emas.

Kata kunci: urgensi, Bank Indonesia, bank sentral syariah 


\section{A. Pendahuluan}

Perkembangan perbankan Syariah di Indonesia telah melaju dengan pesat. Chairiyyah mencatat kondisi itu mulai jelas sejak diberlakukannya UU Nomor 10 Tahun 1998 tentang Perubahan UU Nomor 7 Tahun 1992 tentang Perbankan. ${ }^{1}$ Indonesia Bahkan menjadi negara di kawasan Asia Tenggara yang menjadi motor pengembangan industri perbankan syariah di kawasan ASEAN bersama Malaysia.

Perkembangan positif ini perlu ditindaklanjuti dengan pembenahan ke dalam dan pengembangan ke luar negeri. Penciptaan lingkungan ekonomi keuangan yang merespon keberadaan semua aktivitas keuangan syariah bisa menjadi prioritas. Tugas ini telah diamanatkan kepada Bank Sentral atau lebih dikenal dengan Bank Indonesia (BI) setelah ditetapkan dalam Undang-undang di tahun 2004 selain harus konsisten terhadap pengawasan keuangan konvensional yang ribawi. BI telah memiliki otoritas dalam kebijakan moneter ganda di Negara yang tak jauh berbeda dengan Negara Islam yang menjalankan dual system keuangan.

Pembenahan terhadap peran kebanksentralan Syariah dari BI ternyata memang perlu segera dilakukan. Salah satu perhatian yang muncul dari Meirison yang menyarankan pengadaan perangkat baru yang sesuai dengan bank-bank syariah yang berbeda dengan bank-bank konvensional dan memberikan petunjuk dalam melakukan pengawasan terhadap bank-bank Islam yang tersebar di seluruh wilayah. ${ }^{2}$

BI harus berada pada posisi Bank Sentral yang benar-benar berdasar pada filosofi yang selaras dengan lalu lintas dan aktivitas Syariah meski tetap berjaga di area keuangan konvensional yang bertolak belakang. Lembaga tidak bisa bertindak sebagai orang baik yang melakukan hal yang salah. Keberadaannya sebagai cermin umat Islam, lembaga regulator medium exchange kebutuhan umat untuk berniaga dan

${ }^{1}$ Choiriyah Choiriyah, "Hukum Perbankan Dan Perasuransian Indonesia Dalam Perspektif Hukum Islam," Salam: Jurnal Sosial dan Budaya Syar-i 6, no. 3 (2019): 265280.

${ }^{2}$ M Meirison, "Permasalahan Bank Islam Dan Bank Sentral," Jurnal Lembaga Keuangan dan Perbankan 2, no. 2 (2017): 125-134. 
beribadah, harapan semua umat manusia mendapatkan segala yang nyata terhadap kekayaan yang ia miliki dalam wujud uang.

Meski sejarah keuangan Syariah telah dimulai sejak Nabi Muhammad, Rasulullah pembawa bendera Islam di dunia, namun kehidupan dunia modern memerlukan perhatian yang sungguh-sungguh untuk menjadi syariah. Kompleksitas persoalan keuangan Islam local, nasional hingga global sekarang belum tentu bisa berjalan setelah perdagangan ribawi lebih dominan. Apalagi setelah system sosialis yang memiliki kesamaan instrumen bagi hasil dalam transaksi telah mengalami goncangan,3 maka para stake and holder perlu bekerja keras mendalami nilai syariah dalam perekonomian.

Tantangan keras yang dialami BI sebagai Bank sentral Syariah menjadi perlu mendapat perhatian penuh. Penjelasannya bisa didekati dari perspektif sejarah hokum, baik dari sisi keuangan syariah maupun perjalanan kelembagaan bank sentral sampai sekarang. Dengan uraian seperti demikian bisa dimunculkan beberapa kesimpulan dan saran bagi kemajuan BI dalam posisi bank sentral ke depan.

\section{B. Sejarah Keuangan Islam}

Bagi seluruh masyarakat dunia, uang telah menjadi bagian kehidupan superior dari yang lainnya. Keuangan telah menjadi senjata politik, social, dan ekonomi yang ampuh di dunia modern. Ia berperan penting tidak hanya dalam alokasi dan distribusi sumber daya yang langka, tetapijuga dalam stabilitas dan pertumbuhan ekonomi. Karena sumber-sumber lembaga keuangan berasal dari deposit yang diletakkan oleh bagian yang representative mewakili seluruh penduduk, cukup rasional kalau ia juga dianggap sebagai sumber nasional. Seluruhnya harus digunakan untuk kesejahteraan bagi masyarakat. Namun karena sumbersumber keuangan itu sangat langka maka perlu digunakan dengan keadilan dan efesiensi yang optimal.4

3 F. Setiawan Santoso, "Reformasi Ekonomi Berbasis Bagi Hasil Belajar Dari Sistem Ekonomi Sosialis," Muqtasid: Jurnal Ekonomi dan Perbankan Syariah 2, no. 2 (December 1, 2011): 193.

4 M Umer Chapra, Islam Dan Tantangan Ekonomi: Islamisasi Ekonomi Kontemporer (Surabaya: Risalah Gusti, 1999). 
Pada posisi ide awal, ajaran Islam sama dengan lainnya yang mengakui secara nyata bahwa keberadaan uang sangat penting karena bermanfaat bagi perputaran harta diantara manusia akan terpelihara dan berlangsung dengan cara cepat. 5 Pada Masa Rasulullah, uang yang beredar dalam keuangan masyarakat berbentuk dirham dan dinar yang terbuat dari emas dan perak bukan kertas seperti sekarang.

Menurut al-Gazali dalam Wahyudi, salah satu nikmat Allah adalah telah diciptakannya dinar dan dirham sehingga dengan keduanya tegaklah dunia. Dinar dan dirham adalah benda mati yang pada hakekatnya tidak memiliki manfaat. Akan tetapi manusia membutuhkannya agar dapat mempunyai barang-barang, makanan, pakaian dan semua kebutuhan lainnya. Lebih lanjut ia juga menyatakan bahwa dinar dan dirham merupakan perantara terhadap sesuatu yang diinginkan. Di dalam dinar dan dirham tidak ada manfaat manakala tidak ada keinginan terhadap sesuatu. Al-Gazali lebih lanjut menyatakan bahwa siapa yang memiliki uang, ia bagaikan memiliki semuanya. 6

Kontributor utama modal dalam lalu lintas keuangan Islam (muamalah) adalah ekonomi nyata (economic real), bukan hutang (nonloan). Aktor penyalur keuangan moneter yang digunakan untuk modal usaha dikonsentrasikan dalam bentuk pembiayaan. Dalam aspek teknis, kebijakan moneter Islam demikian harus bebas dari unsur riba yang telah telah diharamkan dengan tegas dan mengalihkan pada pilihan lainnya yang telah disahkan dalam syariah, seperti; bagi hasil atau jual beli termasuk ijarah.

Sejak Awal Islam, Riba telah menjadi perhatian utama agar tidak terjadi dalam dunia keuangan umat. Bahkan Allah telah menetapkannya secara bertahap hingga pelarangannya mendapat status haram. Sayyid Sabiq dalam Fiqh Sunnahnya memberikan beberapa alasan mengapa Islam sangat mengharamkan riba :

\footnotetext{
${ }^{6}$ Amien Wahyudi, "Kebijakan Moneter Berbasis Prinsip-Prinsip Islam,” Justicia
} 2008).

5 Ascarya, Akad Dan Produk Bank Shariah (Jakarta: PT Raja Grafindo Persada, Islamica 10, no. 1 (2013): 57-80. 
a. Riba merupakan penyebab timbulnya permusuhan antar sesama masyarakat. Dan menghilangkan semangat tolong- menolong antara mereka.

b. Riba cenderung melahirkan satu kelas di masyarakat yang hidup mewah tanpa bekerja keras, dan selanjutnya akumulasi kekayaan hanya berada di tangan kelas itu tanpa berusaha, pada gilirannya terus tumbuh dengan subur di atas penderitaan orang lain.

c. Riba adalah penyebab penjajahan. Bila dilihat posisi Indonesia terus berada dalam kesusahan karena terjepit oleh jumlahnya bunga hutang yang harus dibayar bila telah jatuh tempo.

d. Islam menghimbau agar manusia memberikan pinjaman kepada yang memerlukan untuk berbuat kebajikan kemanusiaan (bukan untuk mencari keuntungan di atas penderitaan orang lain. 7

Konsep Islam tentang ribawi telah menyatakan uang dengan hukum-hukum yang harus terkait denganya, jika kita menyadarkan pengandaian barter itu berupa satu ton beras ketan dengan satu pesawat terbang nampak menyulitkan pengadaanya, maka kaitan inilah yang harus ditransformasikan berdasarkan kemampuan alam menyediakan sumber dayanya yang bernilai tinggi yaitu emas dan perak yang terungkap dalam bentuk dirham dan dinar. Ukuran yang demikian itu dianjurkan oleh Allah dalam Q.S At-Taubah (9); 34-35,"Dan orang -orang yang menimbun emas dan perak, serta tidak menafkahkannya dijalan Allah, maka beritahukan kepada mereka, azab yang pedih."8

Rasullah saw telah menetapkan emas dan perak sebagai uang, dan beliau menjadikan hanya emas dan perak sajalah sebagai standar uang, bukan beras ketan. Dimana standar barang (pesawat terbang misalnya) akan dikembalikan kepada standar tersebut. Dan dengan pijakan emas dan perak inilah standar semua bentuk transaksi bisa dilangsungkan. Nabi telah membuat standar uang ini dalam bentuk uqiyyah, dirham, daniq, qirath, mitsqal dan dinar. Rasullah bahkan telah menentukan berat emas

${ }_{7}$ Sayyid Sabiq, Fiqh Sunnah, vol. 3 (Beirut: Dar al-Fikr li al-tiba'ah wa al-nasr wa al-tauzi', n.d.).

8 Lajnah Pentashih Al Qur'an Departemen Agama RI, Al-Quran Dan Terjemahannya (Bandung: Syamil Cipta Media, 2002). 
dan perak tersebut dengan berat tertentu,yaitu timbangan penduduk Mekkah. Imam Abu Daud dan An-Nasa'I telah meriwayatkan dari Ibnu Umar, bahwa Rasullah saw, bersabda : Timbangan tersebut adalah timbangan penduduk Mekkah.9

Uang dalam ajaran Islam memiliki standar yang jujur dan nyata bahwa kavling atas sumber daya alam untuk memenuhi kebutuhan hidup manusia yang berada dikavling itu, betul-betul logistiknya disediakan oleh negara. Jadi batasanya adalah standar emas dan perak, dan dengan berat masing-masing, dimana hak-hak Allah semisal zakat dan hak-hak manusia semisal hutang,serta harga yang dibeli semuanya berhubungan dengan dirham dan dinar, yakni berhubungan dengan emas dan perak yang sudah diperkirakan dengan timbangan-timbangan tertentu.

Selain praktek non-ribawi, Kebijakan moneter pembiayaan demikian berpijak pada prinsip-prinsip dasar ekonomi Islam, yaitu; (a) Kekuasaan tertinggi adalah milik Allah sebagai pemilik yang absolut. (b) Manusia merupakan Pemimpin (khalifah) di bumi, tetapi bukan pemilik yang sebenarnya. (c) Semua yang dimiliki dan didapatkan oleh manusia adalah karena seizin-Nya, dan oleh karena itu saudara-saudaranya yang kurang beruntung memiliki hak atas sebagian kekayaan yang dimiliki saudara-saudaranya yang lebih beruntung. (d) Kekayaan tidak boleh ditumpuk, harus diputar (e) Menetapkan kewajiban ekonomi yang sifatnya wajib dan suka rela bagi semua individu, termasuk bagi anggota masyarakat yang miskin. (f) Transaksi berasas kepastian kontrak dan manfaat untuk kedua belah pihak. (g) Transaksi dilaksanakan dalam rangka mewujudkan kemaslahatan manusia. (h) Zakat sebagai dasar distribusi pendapatan dan kesejahteraan. ${ }^{10}$

Dari situ dirumuskan aturan dasar syariah dalam sistem keuangan yaitu: (a) Kebebasan bertransaksi, namun harus didasari dengan prinsip suka sama suka tanpa unsur paksaan zalim, dengan didasari dengan akad yang sah. (b) Obyek Transaksi berupa produk halal yang tidak haram. (c).

9 Hasanuz Zaman SM, Economic Function of an Islamic State, The Early Experience (Karachi: Islamic Foundation, 1991).

1o Adiwarman Azwar Karim, Sejarah Pemikiran Ekonomi Islam (Jakarta: IIIT, 2001) 
Bebas dari maisir yaitu judi atau spekulatif, garar (penipuan atau ketidak jelasan), riba (pengambilan tambahan dengan cara batil). (d). Bebas dari upaya mengendalikan, merekayasa dan memanipulasi harga. (e). Semua orang berhak mendapatkan informasi yang berimbang, memadai, akurat agarbebas dari ketidaktahuan bertransaksi. (f) Pihak-pihak yang bertransaksi harus mempertimbangkan kepentingan pihak ketiga yang mungkin dapat terganggu, oleh karenanya pihak ketiga diberikan hak atau pilihan. (g) Transaksi didasarkan pada kerjasama yang saling menguntungkan dan solidaritas. Serta harus ada kepastian kontrak dan manfaat untuk kedua belah pihak. (h) Setiap transaksi dilaksanakan dalam rangka mewujudkan kemaslahatan manusia. (i) Mengimplementasikan zakat, sebagai dasar distribusi pendapatan dan kesejahteraan yang merata. ${ }^{11}$

Dewianti dari Chapra kemudian menyimpulkan karakteristik sistem keuangan Islam meliputi;12 (a) Kesejahteraan ekonomi yang diperluas dengan kesempatan bekerja penuh dan lajupertumbuhan yang optimal. (b) Keadilan sosio ekonomi dan distribusi kekayaan dan pendapatan yang merata. (c) Stabilitas nilai mata uang sebagai alat tukar yang dapat diandalkan, standar yang adil bagipembayaran cicilan dan alat penyimpan yang stabil. (d) Mobilisasi dan investasi tabungan untuk pembangunan perekonomian dalam suatu carayang adil sehingga pengembalian keuntungan dapat dijamin bagi semua pihak yangbersangkutan. (e) Memberikan semua pelayanan yang efektif yang secara normal diharapkan dari sistem keuangan.

Sejak pemerintahan Rasulullah, system keuangan negara termasuk system moneter tidak bisa dilepaskan dari otoritas baitul mal. Santoso telah memberikan gambaran singkat tentangnya. lembaga bait mal berisi Harta Tuhan (mal allah) yang juga dinamakan mal muslimin karena pemanfaatan bagi kepentingan umum. Setelah dimasukkan dalam khizanat al-mal yang fungsinya sama dengan bait al-mal menjadi

${ }^{11}$ Shinta Dewianty, "Sistem Lembaga Keuangan Shari'ah," Jurnal Ekonomi Dan Hukum Islam 3, no. 2 (2013): 94-116.

12 Ibid. 
pendapatan pemerintah yang digunakan untuk kepentingan publik. Oleh karena itu Pengelolalan bait al-mal dipisahkan dari kekayaan yang berstatus hak milik pribadi khalifah (Mal Khass). Disini juga terkumpul zakat dan pajak jizyah yang masing-masing dikumpulkan dari warga muslim dan muslim. Selain itu, persoalan pembiayaan jaminan social termasuk pengawasan keuangan lainnya berada di tangan pengampunya berkordinasi dengan al-Hisbah, lembaga yang secara umum berfungsi sebagai pelaksana amar makruf nahi munkar. ${ }^{13}$

Pada masa Pemerintahan rasulullah memang masih mengandalkan keuangan dalam sistem transakasi barter namun dengan keunikan tersendsiri setelah ada pengharaman riba. Wahyudi mencatat Valuta asing dari Persia dan Romawi yang dikenal oleh seluruh lapisan masyarakat Arab, bahkan menjadi alat bayar resminya adalah dinar dan dirham. Sistem devisa yang bebas telah ditetapkan dimana tidak ada halangan sedikitpun untuk mengimpor dinar dan dirham. ${ }^{14}$

Di masa Khulafa Rasyidin system moneter berkembang namun tetap dengan pengharaman praktek ribawi. Daniar dari Ningsih menceritakan bahwa Khalifah Umar yang telah mengatur sektor moneter dengan berbagai peraturan diantaranya: (1) Melarang segala bentuk tindakan yang berdampak pada bertambahnya gejolak dalam daya beli dan ketidakstabilan nilai uang; (2) Melarang pemalsuan uang; (3) Melakukan perlindungan pada inflasi dengan cara memberikan himbauan kepada masyarakat untuk melakukan investasi modalnya pada sektor riil, hidup sederhana dan tidak bergaya hidup berlebih-lebihan; (4) Mencetak dirham yang sesuai dengan ketentuan Islam, yaitu sebesar enam daniq. ${ }^{15}$

Dalam perjalanan sejarah selanjutnya tercatat pada Pemerintahan Abdul Malik telah dibentuk suatu institusi yang mencetak uang dirham dari perak dan dinar dari emas. Otoritas pencetakan uang pada era modern dinamakan Bank Sentral. Peristiwa tersebut terjadi pada tahun ke

13 F. Setiawan Santoso, "Peran Bait Mal Dalam Jaminan Sosial Di Era Fikih Klasik,” Ulumuddin : Jurnal Ilmu-ilmu Keislaman 2, no. 2 (2017): 117-136.

14 Wahyudi, "Kebijakan Moneter Berbasis Prinsip-Prinsip Islam.”

15 Daniar, "Transmisi Kebijakan Moneter Syariah: Sebuah Analisa," Falah: Jurnal Ekonomi Syariah 1, no. 1 (2016): 91. 
75 Hijriyah. keduanya kemudian dicetak oleh Bank Sentral Syariah secara berkelanjutan. Lembaran sejarah tentang uang inilah dapat dikatakan sebagai cikal bakal keberadaan Bank Sentral Syariah dan dari sanalah lahirnya uang Islam dan dimulai sejak tanggal itulah uang Islam berstandar emas dalam bentuk dirham dan dinar menjadi khas mengikuti satu ciri khas yang tidak berbeda-beda lagi. ${ }^{16}$

Bnetuk bank sentral dalam Islam telah mengalami perkembangan yang dinamis. Sesuai dengan pendapat Masykur, prinsip- prinsip dasar ekonomi syariah melalui bank syariah adalah nilai-nilai etika dan norma ekonomi yang universal dan komprehensif. Keuniversalan itu sengaja diberikan pada umat untuk memberikan kesempatan agar berinovasi (ijtihad) dan berkreasi (jihad) dalam mengatur sistem ekonominya dengan syarat tidak keluar dari kerangka umumnya. Dengan demikian sistem ekonomi Islam akan valid dan cocok untuk setiap perubahan waktu dan perbedaan tempat dan umat Islam mampu memerankan fungsinya sebagai kholifah di muka bumi ini. ${ }^{17}$

\section{Problematika Bank Sentral Konvensional}

Menurut penulis uang dengan standar emas (gold standar) memiliki beberapa sifat :

1. Nilai transformasi tetap, karena uang merupakan simpanan nilai yang bagus, bayangkan jika kita tidak memerlukan apa-apa karena barangbarang tersedia sudah penuh. Kmudian kita akan menukarkan uang riil yang kita miliki itu pada Bank Sentral, disana sudah ada standardnya yaitu emas. Berbeda dengan Uang Fiat Money sebagaimana dijelaskan dimuka yang bisa kita lakukan untuk mentransformasikan itu adalah kehampaan, karena uang hanya bernilai sebuah kerupuk.

2. Fasilitas pertukaran yang nyata. Uang akan bersikulasi paralel sebagai sesuatu yang terberi dan tidak dapat diubah, pencetakan uang memneuhi unsure keadilan, karena pada dirinya sudah mengandung harta. Sehingga uang ini adalah uang yang adil.Berbeda dengan uang

\footnotetext{
16 Taqiyuddin An-Nabhani, Sistem Ekonomi Islam (Edisi Mu'tamadah) (Jakarta: HTI Press, 2005); SM, Economic Function.

${ }_{17}$ M Ali Mansyur, "Aspek Hukum Perbankan Syariah Dan Implementasinya Di Indonesia,” Jurnal Dinamika Hukum 11, no. Edsus (2011).
} 
kertas fasilitas ini akan digunakan untuk mencetak uang secara besarbesara. Uang ini dapat diintroduksi secara besar-besaran setelah diketemukannya mesin cetak modern. Uang bersirkulasi tidak paralel dengan bukti dirinya.

3. Non komoditas. Pada sistem Uang kertas Fiat Money uang sebagai komoditas dapat digunakan untuk memfasilitasi proses pertukaran dan penjualan uang terhadap diri uang itu sendiri dan barang- jasa. Kelangkaan barang menjadi tolok ukur komoditas. Pertanyaanya mana yang dibutuhkan terlebih dahulu apakah barang atau uang.

4. Jika uang hanya sebetas lembaran angka legal dicetak oleh yang berwenang maka uang selalu diadakan meskipun jumlah angkanya tidak pararel dengan dengan angka yang tidak tetaap itu. Bagaimana bisa anda menentukan Rp 1 itu berarti untuk alat tukar sekarang ini. Angka satu rupiah tidak lebih berharga dengan kotoran manusia atau kotoran hewan, yang bisa dijual sebagai pupuk. Namun, jika satu rupiah itu secara riil dapat ditukar dengan 1 gram emas. Maka nilai satu gram emas adalah satu rupiah dst. Perumpaan yang salah sebagaimana dikutip dari penelitian ISRA Bahwa jika uang disetarakan dengan sekantng beras ketan, betapa repotnya dunia ini. Karena setiap orang harus membawa kantong beras untuk ditukar dengan barang lain. Dan jangan salah berapa besar gudang-gudang beras yang dibangun oleh Bank Central dan berapa banyak diadakan oleh BI.

Situasi kemudian berubah. Pada tanggal 15 Agustus 1971, Presiden Nixon mengakhiri hubungan antara Dolar Amerika Serikat dan emas. Dolar berbahan kertas telah menjadi uang monopoli dunia. Setelah itu, ledakan ekonomi terbesar dalam sejarah telah dimulai. ${ }^{18}$ Penyaluran uang pun menjelma menjadi konsep hutang dalam berbagai bentuknya, diantaranya adalah penggunaan uang sebagai instrumen modal.

Permainan monopoli modal dewasa ini telah berbentuk percaturan politik moneter sehingga menjerumuskan ke arah penumpukan hutang. kondisi ini membelenggu seluruh kehidupan manusia. hidup telah

18 Robert T Kiyosaki, Rich Dads Conspiracy of The Rich The 8 New Rules of Money, trans. Ratu Fortuna Rahmi Puspahadi (Jakarta: Gramedia Pustaka Tama, 2010). 
menjadi taruhan nyawa tak berujung. kehidupan sekarang ini dibiayai oleh penghasilan yang akan datang yang masih dalam bentuk harapan. Pola hidup yang berjalan sekarang bergantung pada hutang.

Penyimpangan-penyimpangan pun berlanjut. Hitchcock ungkap aib bank sentral itu pada salah satu bukunya yang berjudul The History of The Money Changer.19 Ekonom dan bankir senantiasa membohongi masyarakat bahwa resesi dan depresi adalah bagian alami dari siklus perdagangan meski pada kenyataanya tidaklah seperti itu. Penderitaan itu justru terjadi karena bank sentral memanipulasi jumlah uang beredar, yang tujuan akhirnya adalah memastikan semakin banyak kekayaan yang ditransfer dari masyarakat ke tangan mereka.

Kenapa demikian? karena menurut pendapatnya bahwa Bank Sentral telah berubah menjadi metamorphosis dari pedagang uang di zaman dulu. Konsep ini merupakan dasar penerapan ekonomi dunia dan pada akhirnya sudah menjadi sistim pembiayaan dunia, menurut Hitchcock sistem ini menciptakan banyak pecundang, dan beberapa pemenang.

Ia selanjutnya mengutip Clemenceau yang mengatakan uang adalah masalah yang lebih serius untuk diserahkan kepada Bank Sentral. Friedman juga akan menyatakan senada dengan menjelaskan bahwa tidak ada depresi berat, di negara atau disetiap waktu, tanpa disertai penurunan tajam persediaan uang. Begitu juga, tidak ada penurunan tajam stok uang yang tidak disertai depresi berat.

Kontruksi pendapat yang lain adalah dari Sir Josiah Stamp, salah satu direktur Bank of England, membuat pernyataan berikut berkaitan dengan perbankan.

1) Sistem perbankan modern memproduksi uang dari ketiadaan. Proses ini mungkin bagian yang paling mengejutkan dari segala sulap yang pernah diciptakan. Perbankan dikandung dalam rahim kejahatan dan lahir dalam dosa. Bankir memiliki bumi. Bawalah bumi menjauh dari

19 Andrew Hitchcock, History of Money, Membongkar Kejahatan Zionis Menjajah Dunia Melalui Manipulasi Uang, trans. Satya Pradana (Jakarta: Melvana Media Indonnesia, 2015). 
mereka dengan kekuasaan untuk menciptakan uang, dan dengan jentikan pena mereka akan menciptakan uang untuk membelinya kembali lagi.

2) Ambilah kekuatan besar ini dari mereka dan hilangkan semua kekayaan besar seperti tambang, maka mereka akan menghilang, kefanaan mereka ini menyebabkan dunia akan menjadi lebih baik. Dan lebih bahagia . Tetapi jika Anda ingin terus menjadi budak bank yang memproduksi uang dari ketiadaan ini, anda sesungguhnya telah membayar perbudakan Anda sendiri, dengan demikian Anda meyakini dan telah menyerahkan hidup ini dengan membiarkan bankir-bankir Bank Sentral menciptakan uang itu dan mengontrol utang Anda (Kredit ). ${ }^{20}$

Bank Sentral sekarang telah menjelma menjadi seperti orangorang yang baik sebagai regulator keuangan, namun sesungguhnya telah melakukan hal yang salah karena tindakan tentang uang dicetak itu hanyalah selembar kertas bergambar angka-angka. Umat manusia tidak memiliki harapan masa depan dengan uang yang ia miliki, seandainya manusia ini berbondong-bondong menukarkan uangnya pada Bank Sentral ,maka bank sentral tidak bisa menggantikan jumlah uang yang mereka miliki dengan sejumlah emas atau benda berharga lainnya.

Katakanlah kita memiliki selembar uang kertas Rp 1000, - (uang Indonesia), apakah angka seribu itu cermin kekayaan kita yang banyak. Harapan kita hidup di Indonesia dengan memiliki Uang Rp 1000,- bila kita tukarkan dengan benda, hanya mendapatkan satu buah kerupuk.

Kalau kita memiliki selembar kertas uang nominal seratus ribu, artinya bahwa kekayaan kita hanya seratus kerupuk. Esensinya yang perlu bagi Bank Sentral Konvensional adalah bukan menyediakan gudang emas tapi sudah cukup hanya menyediakan kaleng kerupuk, bahkan mungkin hanya kantong plastik. Jadi kalau kita datang ke BI untuk menukarkan uang Rp 1000,- akan mendapatkan satu buah kerupuk.

20 Ibid. 
Kerupuk itu kemudian kita bawa pulang, dan kita simpan, seberapa lama nilai kekayaan yang berwujud kerupuk itu bisa kita simpan, satu hari dua hari kerupuk itu mlempen dan lenyap tidak berarti apa-apa. Uang Rp 1000,- ternyata hanya sesuatu yang tidak berarti apa-apa. Angka 1000 pada lembar kertas uang rupiah bukan cermin kekayaan yang berlimpah akan tetapi adalah cermin dari ketidakadilan umat manusia terhadap dirinya sendiri. Bank Sentral yang mencetak uang tanpa standart medium exchange menimbulkan ketidak pastian moneter.

Uang kertas seperti dolar tidak lagi berfungsi sebagai sertifikasi utang. Fondasi sekarang uang berbasis legalitas. Bank hanyalah pencatatan utang yang mana hanya sekedar merupakan sertifikat utang terbukti, yang dapat ditransfer. Semua pemegang nota keuangan (monetary notes)akan merupakan kreditur IOU tersertifikasi. Mereka yang meminjam uang dibank dan memanfaatkanya di pasar untuk membeli beragam barang dan jasa akan merupakan debitur. Bank hanya sebagai entitas pencatat sedangkan Bank Sentral berfungsi hanya sebagai lembaga kliring yang sangat besar.

Di sisi lain, Jika uang kertas hanya sebagai nota janjian (moneteray notes), atau sekedar IOU, maka bank hanyalah sebagai perantara antara kreditor dan debitor. Namun aneh, syarat-syarat kredit yang seharusnya ditentukan oleh persetujuan timbal-balik diantara para pihak yang terlibat, dan koersi tidak boleh diberlakukan, terutama jika transaksi tersebut dikehendaki menjadi patuh syrai'ah. Namun IOU masa kini diterbitkan tanpa persetujuan para kreditur, yakni pinjam-pinjaman diberikan kepada para debitur tidak ada keterlibatan para kreditur. Kapan saja ban-bank memutuskan untuk meningkatkan suplai uang, sebenarnya mereka sudah melaksanakan sebelumnya. Keberadaan keputusan tersebut tidak perlu persetujuan kreditur manapun. Bank Sentral, dengan demikian, tidak berfungsi lagi dalam hal ini. Lembaga itu tidak perlu menyelidiki kerelaan dan persetujuan masyarakat menyediakan kredit.

Paradigma kehidupan semacam ini, harus segera dirobah dengan mendirikan Bank Sentral Syariah agar bangunan kehidupan tidak lagi dibiayai dengan hutang. Lingkungan ekonomi dikondisikan dalam 
pembiayaan yang adil yang dapat dikombinasikan dalam dual sistem Bank Sentral.

\section{Menuju Bank Sentral Yang Adil}

Konsep Bank sentral telah identik dengan industri uang yang tidak jelas sehingga gagal menunjukan perbedaan dengan keuangan/ perbankan bernuansa Islami, karena semua industri keuangan di bawah satu wadah yaitu bank sentral berbasis bunga. Konsep itu adalah konflik paham senyata-nyatanya terhadap dunia perbankan konvensional tapi dominan yang bernuansa neo liberalis dengan keuangan Islam yang asketis dalam kesucian syariah. Perbedaan infrastuktur yang seharusnya muncul dengan pemisahan bank sentral berdasar prinsip dasar tidak bisa terjadi karena keduanya tumbuh dalam jantung infrastruktur bank sentral yang sama.

Inilah saatnya World Bank Group memberikan komitmen pada dunia Islam, mendorong pada negara-negara islam yang menganut dual sistem perbankan segera mendirikan Bank Sentral Syariah. Bank Sentral ini berkedudukan di Ibukota Negara adalah institusi lembaga keuangan tertinggi umat islam yang bertanggung jawab atas kebijakan moneter terhadap bank-bank yang berbasis syariah.

BI Syariah harus sadar untuk tidak mengulangi kembali sikap orang baik yang melakukan hal yang salah dengan berpegang pada filosofinya. sistem uang di dalam Islam-dari segi asasnya-mengikuti timbangan (collateral dan dijamin) dengan emas dan perak. Adapun berat, cetakan, bentuk dan model ukirannya, semuanya hanya merupakan masalah teknis. ${ }^{21}$

Pegangan filosofi kedua adalah konsistensi dengan keberadaannya sebagai lembaga regulator medium exchange, kebutuhan umat untuk berniaga dan beribadah, harapan semua umat manusia mendapatkan segala yang nyata terhadap kekayaan yang ia miliki dalam wujud uang. Ketiga, memiliki otoritas mencetak uang berstandard emas dengan emberlakuan prinsip Islam, uang adalah emas.

${ }^{21}$ An-Nabhani, Sistem Ekonomi. 
Bank Sentral Syariah selanjutnya berfungsi sebagai pintu gerbang terakhir lalu lintas keuangan Islam. Fungsi utamanya adalah, sebagaimana bank sentral lainnya, Lender of Last Resort atau LOLR. Meski demikan, penjaga dan pengawas harga atau stabilitas nilai mata uang, stabilitas sektor perbankan, dan sistem mata uang pada suatu Negara adalah termasuk di dalamnya.

LOLR (lending of last resort) yang dimaksud telah sesuai kaidah bagebot. $^{22}$ Konsep Real Bills Doctrine sejalan dengan Bank Sentral Syariah berdasarkan sejarahnya sebagai penjaga stabilitas nilai mata uang dan menyimpan emas dan perak secara keseluruhan. Uang yang dikelola oleh Bank Sentral Syariah adalah uang yang berstandar emas dan perak.

Penerbitan uang dengan berstandar emas dapat dimungkinkan berdiri manakala instrument perbankan yang sudah ada terutama Bank Syariah membentuk induk Bank dalam komunitas uang berstandar emas dan perak. Maka bila di dalam negeri mempergunakan mata uang kertas yang bisa ditukarkan dengan emas, dengan kurs tetap. Artinya,satuan uang kertas itu di jamin dengan emas dalam bentuk statement Banking.

Dengan alur pemikiran filosofi dan fungsi dapat diuraikan tugas pokok BI Syariah kemudian bisa dijabarkan sebagai berikut;

1) Pengawasan Bank Umum Syariah dan Bank Perkreditan Rakyat Syariah ,

2) Menjual dan memperdagangkan surat-surat berharga berbasis saham dari pembiayaan bank syariah dengan nama Saham Syariah

3) Surat Akad, dalam bentuk komitmen debitor digunakan sebagai instrumen keuangan, antar bank syariah .

4) Instrumen Swift, dengan kode-kode khusus berbeda dengan Bank Konvensional.

5) Collateral non loan.

6) Contract berbasis Ijab - Qabul.

7) Fractional Banking System.

E. Penutup

22 Perry Warjiyo and Solikin M Juhro, Kebijakan Bank Sentral Teori Dan Praktek (Jakarta: PT. Radja Grafindo Persada, 2016). 
Dalam kondisi dual system keuangan seperti Indonesia, Bank Sentral yang lebih dikenal secara resmi dengan Bank Indonesia (BI) perlu segera melakukan kebijakan dan tindakan Rekonsiliasi mata uang. Hal penting itu untuk mengapreasiasi keberlakuan uang terhadap barang dan jasa yang adil, konsep rekonsialisai ini menafsirkan uang sebagai alat pembayaran murni dan tidak berbasis utang. Doktrin non utang sebagai implementasi hukum syariah membangun perisai keadilan terhadap alat tukar harga, karena harga dari kopentensinya adalah sesuatu yang berharga,maka kontraksinya adalah menyediakan alat pembayaran yang melahirkan "uang" berbasis standar jaminan berharga.

Bila hal ini dapat dilaksanakan, maka BI harus menyediakan uang sendiri tanpa biaya. Keberadaan seperti itu bisa membebaskan pemerintah dari utang. Negara akan memiliki uang yang dimiliki untuk menjalankan perdagangan sehingga makmur di luar preseden dalam sejarah pemerintahan dunia global di era dewasa ini. Sumber dana murah bisa bersumber dari uang hasil pengumpulan zakat dikompensasikan dengan wujud emas yang nyata disimpan sebagai modal Bank Indonesia Syariah.

Seiring dengan semua tindakan itu, maka penyusunan maupun penyesuaian hokum yang berkaitan perlu dilakukan terlebih dahulu. Langkah harmonisasi hokum ini bisa antara antar fikih dan hokum Islam bidang keuangan fikih dan hokum Islam bersama peraturan kebanksentralan konvensional, atau antar kebangksentralan syariah. Di Indonesia strategi demikian telah berjalan di bidang hokum lain, 23 dan perlu diperluas ke wilayah keuangan termasuk dalam peraturan BI sendiri.

\section{Daftar Pustaka}

An-Nabhani, Taqiyuddin. Sistem Ekonomi Islam (Edisi Mu'tamadah). Jakarta: HTI Press, 2005.

Ascarya. Akad Dan Produk Bank Shariah. Jakarta: PT Raja Grafindo Persada, 2008.

Chapra, M Umer. Islam Dan Tantangan Ekonomi: Islamisasi Ekonomi Kontemporer. Surabaya: Risalah Gusti, 1999.

Choiriyah, Choiriyah. "Hukum Perbankan Dan Perasuransian Indonesia

23 M. Nurkholis Al-Amin and Nurjidin Nurjidin, "Hubungan Negara-Ummah Dalam Hukum Indonesia Dan Islam," Ulumuddin : Jurnal Ilmu-ilmu Keislaman 7, no. 2 (2017): 103-116; Cipto Sembodo, "Dari Khilafah Ke Nation-States: Transformasi Hukum Islam Era Modern,” Ulumuddin : Jurnal Ilmu-ilmu Keislaman 6, no. 2 (2016): 136-150. 
Dalam Perspektif Hukum Islam." SALAM: Jurnal Sosial dan Budaya Syar-i 6, no. 3 (2019): 265-280.

Daniar. "Transmisi Kebijakan Moneter Syariah: Sebuah Analisa." Falah: Jurnal Ekonomi Syariah 1, no. 1 (2016): 91.

Dewianty, Shinta. "Sistem Lembaga Keuangan Shari'ah.” Jurnal Ekonomi Dan Hukum Islam 3, no. 2 (2013): 94-116.

Hitchcock, Andrew. History of Money, Membongkar Kejahatan Zionis Menjajah Dunia Melalui Manipulasi Uang. Translated by Satya Pradana. Jakarta: Melvana Media Indonnesia, 2015.

Karim, Adiwarman Azwar. Sejarah Pemikiran Ekonomi Islam. Jakarta: IIIT, 2001.

Kiyosaki, Robert T. Rich Dads Conspiracy of The Rich The 8 New Rules of Money. Translated by Ratu Fortuna Rahmi Puspahadi. Jakarta: Gramedia Pustaka Tama, 2010.

Lajnah Pentashih Al Qur'an Departemen Agama RI. Al-Quran Dan Terjemahannya. Bandung: Syamil Cipta Media, 2002.

M. Nurkholis Al-Amin, and Nurjidin Nurjidin. "Hubungan NegaraUmmah Dalam Hukum Indonesia Dan Islam." Ulumuddin : Jurnal Ilmu-ilmu Keislaman 7, no. 2 (2017): 103-116.

Mansyur, M Ali. “Aspek Hukum Perbankan Syariah Dan Implementasinya Di Indonesia.” Jurnal Dinamika Hukum 11, no. Edsus (2011).

Meirison, M. "Permasalahan Bank Islam Dan Bank Sentral." Jurnal Lembaga Keuangan dan Perbankan 2, no. 2 (2017): 125-134.

Sabiq, Sayyid. Fiqh Sunnah. Vol. 3. Beirut: Dar al-Fikr li al-tiba'ah wa alnasr wa al-tauzi', n.d.

Santoso, F. Setiawan. "Peran Bait Mal Dalam Jaminan Sosial Di Era Fikih Klasik.” Ulumuddin : Jurnal Ilmu-ilmu Keislaman 2, no. 2 (2017): 117-136.

- - . "Reformasi Ekonomi Berbasis Bagi Hasil Belajar Dari Sistem Ekonomi Sosialis.” Muqtasid: Jurnal Ekonomi dan Perbankan Syariah 2, no. 2 (December 1, 2011): 193.

Sembodo, Cipto. "Dari Khilafah Ke Nation-States: Transformasi Hukum Islam Era Modern.” Ulumuddin : Jurnal Ilmu-ilmu Keislaman 6, no. 2 (2016): 136-150.

SM, Hasanuz Zaman. Economic Function of an Islamic State, The Early Experience. Karachi: Islamic Foundation, 1991.

Wahyudi, Amien. "Kebijakan Moneter Berbasis Prinsip-Prinsip Islam." Justicia Islamica 10, no. 1 (2013): 57-80.

Warjiyo, Perry, and Solikin M Juhro. Kebijakan Bank Sentral Teori Dan Praktek. Jakarta: PT. Radja Grafindo Persada, 2016. 
Agus Pandoman 